\title{
Morphological, hormonal, and molecular changes in different maternal tissues during lactation and post-lactation
}

\author{
Gustavo Canul-Medina $^{1} \cdot$ Cristina Fernandez-Mejia $^{1}$ (D)
}

Received: 2 May 2019 / Accepted: 13 September 2019 / Published online: 28 September 2019

(c) The Physiological Society of Japan and Springer Japan KK, part of Springer Nature 2019

\begin{abstract}
Milk supply and quality during lactation are critical for progeny survival. Maternal tissues and metabolism, influenced by hormonal changes, undergo modification during lactation to sustain breastfeeding. Two organs that suffer essential adjustment are the mammary glands and the bone; however, renal calcium conservation and calcium absorption from the intestine are also modified. Lactation leads to a transient loss of bone minerals to provide adequate amounts of minerals, including calcium for milk production. Physiological, metabolic, and molecular changes in different tissues participate in providing nutrients for milk production. After weaning, the histological, metabolic, and hormonal modifications that take place in lactation are reverted, and bone remineralization is a central function at this time. This study focuses on the hormonal, metabolic, molecular, and tissue modifications that occur in mammary glands, bone, intestine, and kidneys in the mother during lactation and post-weaning periods.
\end{abstract}

Keywords Lactation $\cdot$ Mammary gland $\cdot$ Bone $\cdot$ Intestine

\section{Introduction}

Lactation and post-weaning are periods during which several tissues suffer morphologic, metabolic, and hormonal changes. The central function of lactation is to synthesize and release milk; mammary glands change to meet the demand for milk production. In the bone, lactation leads to a transient loss of bone minerals to ensure adequate amounts of minerals, including calcium, for milk production. Other organs such as the gut and the kidney also modify their functions to support the levels of calcium and other nutrient requirements. After weaning, the mammary glands undergo involution, and the modifications in other tissues to sustain breastfeeding are reverted; in particular, bone remineralization is a focal feature during this period.

Calcium is a central protagonist in lactation and post-lactation. Plasma calcium exists in three distinct forms: approximately $15 \%$ is bound to organic and inorganic anions, $40 \%$

Cristina Fernandez-Mejia

crisfern@biomedicas.unam.mx

1 Unidad de Genética de la Nutrición, Instituto de Investigaciones Biomédicas, Universidad Nacional Autónoma de México/Instituto Nacional de Pediatría, Av. del Iman \#1, 4th Floor, 04530 Mexico City, Mexico to albumin, and the remaining $45 \%$ circulates as free ionized calcium. About $99 \%$ of the calcium is stored in the bones and the teeth as hydroxyapatite [1]. The total calcium is maintained within a range of $8.5-10.5 \mathrm{mg} / \mathrm{dl}(4.3-5.3 \mathrm{mEq} / \mathrm{L}$ or 2.2-2.7 mmol) [2]. However, normal values and reference ranges may vary among laboratories by as much as $0.5 \mathrm{mg} /$ dl. In a non-lactating state, parathyroid hormone and calcitriol regulate calcium homeostasis.

In lactation, the hormones produced intervene in calcium metabolism (described below). The mechanisms by which calcium is provided for milk synthesis may differ between species [3]. Reports in rodents indicate a loss of 25-35\% of bone mass during lactation. Women lose less bone mass (5-8\%) than rodents over the first 6 months after parturition, because humans usually nurse only one child versus multiparous rodents [3]. The main adaptation to provide calcium for milk synthesis is bone demineralization, followed by the renal conservation of calcium [3]. Rodents also have increased intestinal calcium absorption during pregnancy [3].

\section{Mammary gland}

Mammary glands are specialized and complex secretory tissues that produce milk to feed the newborn. They contain 
epithelial cells, adipocytes, vascular endothelial cells, fibroblasts, and immune cells [4].

\section{Mammary gland changes during lactation}

Mammary glands change during pregnancy and culminate in lactation [5]. These changes require increased epithelial cell proliferation and differentiation in the milk-producing alveoli secretory gland (alveologenesis). On the other hand, the number of adipocytes decreases and vascularization increases in the mammary gland. At the end of pregnancy, the alveoli occupy most of the adipose space [5]. Lactation in rats is at its peak on day 12 after delivery, the period in which the mammary glands present prominent luminal structures and ducts and few visible adipocytes [5].

For the development of mammary glands during pregnancy, increase in progesterone and estrogen levels is essential. After delivery, the decrease in estrogen and progesterone levels facilitates the effect of prolactin in milk synthesis [3]. Suckling stimulates the hypothalamus to secrete oxytocin and prolactin. The augment of prolactin produced by suckling is pulsatile throughout lactation [3]. Prolactin is also produced by the breast during lactation [3]. The increase of this hormone produces several metabolic changes to promote lactogenesis.

\section{Metabolic changes}

During lactation, numerous changes in maternal metabolism, triggered by hormonal signals, occur to fulfill the nutrient, energy, and mineral requirements for milk production [6]. In the breasts, increased glucose utilization, fatty acid esterification, and lipid and amino acid uptake occur [7, 8]. Prolactin regulates lactogenesis and increases the synthesis of milk proteins, such as $\beta$-casein [9], lactoglobulin [10], $\alpha$-lactoalbumin [11], and whey milk acid protein [12]. It also augments the enzymes and transporters involved in lipid uptake and de novo lipogenesis [13] as well as the enzymes that participate in lactose synthesis [14].

Lactose is the main carbohydrate component of the milk; this disaccharide is synthesized from glucose. Early rat studies from the Dermot Williamson group (1980) [15] estimated that in the mammary gland, the glucose uptake for lactose synthesis is about $23 \%$, and the rest is for lipogenesis [15]. During lactation, the mammary gland is the most active site for both lipid synthesis (fivefold higher than the liver) and fatty acid esterification [7]. Mammary glucose-transport activity raises with a concomitant increase in glucose transporters (GLUT) GLUT-8 and GLUT-1; this later is the predominant isoform that transports mannose and galactose in addition to glucose $[16,17]$. Despite the importance of glucose in milk synthesis, there is not a complete understanding of the factors that trigger the transport of glucose by mammary glands. Prolactin together with glucocorticoids and the growth hormone increase glucose transport [18]; however, recent studies have found that GLUT's expression was not affected by lactogenic hormones [19] and that the regulation of GLUT1 and glucose uptake is probably elicited by hypoxia [16]. Other studies suggest that serotonin may participate in the expression of GLUT transporters [20].

Studies by Rudolph et al. [21] examined by microarray analysis the expression of genes contributing to milk synthesis in the mammary gland, comparing the ratio of gene expression at lactation on day 2 to pregnancy on day 17. Important increases were found in lactose synthesis enzymes with a remarkable change of 15 -fold in the alpha-lactoalbumin expression [21]. Increased glycolysis, pentose phosphate shunt, fatty acid/malate shuttle, and citric acid cycle enzymes were observed, especially enzymes involved in the regulation of lipogenesis de novo [21], such as aldolase, pyruvate kinase, and citrate kinase. Important increases in glucose transporter GLUT1, fatty acid uptake such as fatty acid plasma membrane transporters, fatty acid translocase, and lipoprotein lipase have also been observed [21,22]. Accordingly, with the high lipid levels in milk, the triglyceride synthesis enzymes glycerol kinase, long-chain acetyl-CoA synthase, 1-acylglycerol-3-phosphate O-acyltransferase-1, and diacylglycerol O-acyltransferase-1 were also upregulated [21]. The mRNA expressions of amino acid transporters as L-amino acid transporter (LAT-1) and the alanine serine cysteine (ASC) system were enhanced [21]. In rats, the expressions of LAT-1, ASC mRNA, and cationic amino acid transporter (CAT-1) were also increased. In contrast, the expression of the transporters for anionic amino acids EAAC1 and GLAST was low (Fig. 1).

The analysis of the signals regulating the expression of these enzymes and transporters in Rudolph studies [21] suggests that the lipogenic transcription factors $\mathrm{C} /$ EBPS, LXR $\beta$, PPAR $\gamma$, and SREBP1c play an important role in the upregulation of lipid synthesis, in particular SREBP1c whose increase was paralleled with augments in transcripts of genes known to be regulated by this factor. The mRNA expression of the signaling protein AKT1 was greatly enhanced; this protein is known to upregulate glucose uptake, GLUT1 surface localization, as well as lipogenic enzymes during lactation [23]. Accordingly, with the central action of prolactin, the transcripts of prolactin signaling pathway, STAT5a, STAT5b, and the prolactin receptor (PRLR) were increased [21].

Interestingly, glucose utilization, lipogenesis, and lipid uptake decrease in the white adipose tissue [15], which indicates that adipocyte metabolism is modified to provide substrates for fat and lactose synthesis in the mammary gland. 
Fig. 1 Enzyme and protein increase in alveoli cells during lactation. GLUT-1 glucose transporter-1, $L P L$ lipoprotein lipase, LAT-1 L-amino acid transporter system, $A S C$ alanine serine cysteine system, Fabp fatty acid-binding protein, DHAP dihydroxyacetone phosphate, Agpat-1 1-acyl glycerol3-phosphate O-acyltransferase-1, Agpat-2 diacylglycerol O-acyltransferase-2

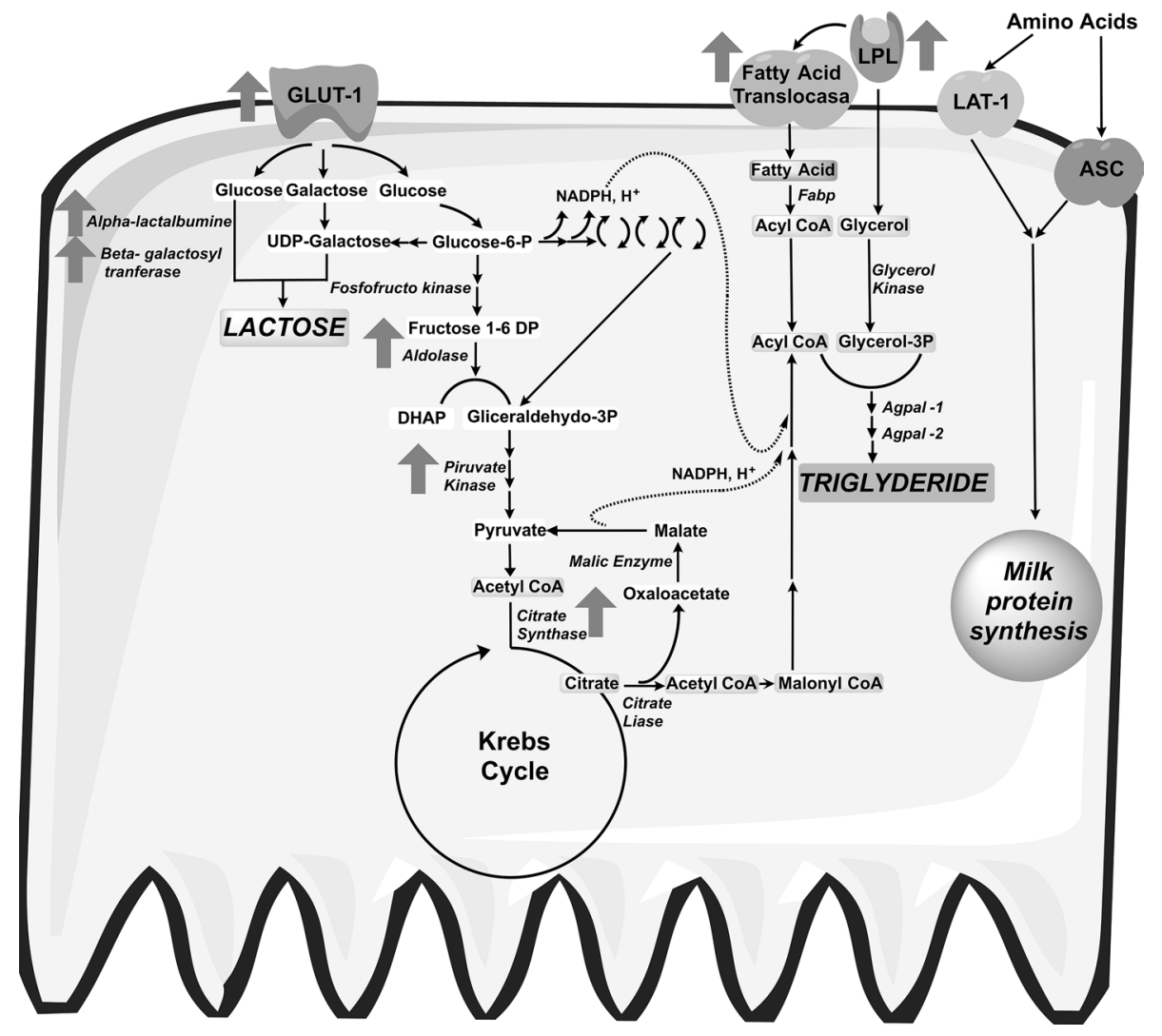

\section{Changes in hormones produced by the mammary gland during lactation}

\section{Prolactin}

Prolactin is a 198-amino acid protein $(23 \mathrm{kd})$ produced in the lactotroph cells of the pituitary gland, which is known for its ability to promote lactation [24]. Prolactin is crucial in the growth and development of mammary glands (mammogenesis), alveologenesis, milk protein synthesis, and maintenance of milk secretion (galactopoiesis) [24]. Prolactin actions are mediated by prolactin receptor (PrlR), which activates Janus kinase 2 (JAK2)/signal transducers and activators of transcription (STAT5), MAP kinase, and phosphoinositide-3 kinase/AKT1 pathways [25].

Growth, development, and survival of mammary cells take place at pregnancy and are mediated through prolactin signaling via PrlR and the Jak2/Stat5A pathway [26], inducing the cytokine receptor activator of nuclear factor $\kappa \mathrm{B}$ ligand (RANKL) [27], which via its receptor RANK activates NF-kB, MAPKs, and AKT [28]. In addition to its actions on the hyperplasia of mammary epithelial cells, RANKL also participates in bone resorption [27]. Moreover, the prolactin-induced expression of E74-like factor 5 (Elf5) is also required for the differentiation of alveolar cells [28].
Prolactin in addition to stimulating Jak2-Stat5 signaling also activates the PI3K-Akt pathway [25, 29]. These two signaling cascades mediate milk production. Stat5 regulates milk protein gene transcription, such as whey acidic protein (WAP), $\beta$-lactoglobulin, and $\beta$-casein genes, via its binding to gamma-activated sequence GAS sequences within promoter regions $[25,26]$. On the other hand, Akt1 regulates glucose transport, lactose synthesis, and lipid synthesis. Importantly, prolactin promotes calcium delivery from the bone to the mammary gland via parathyroid hormonerelated protein (PTHrP) secretion by the mammary tissue.

\section{Parathyroid hormone-related protein}

PTHrP is a hormone with homology to parathyroid hormone. It plays an essential role in regulating calcium homeostasis during lactation via bone resorption [30, 31]. The source of the parathyroid hormone-related protein during lactation is the mammary gland, where its mRNA and protein synthesis are upregulated [30, 31]. At the end of lactation, the fall in progesterone and estradiol, which occurs after delivery, accelerates parathyroid hormone-related protein production [32]. Suckling also induces its mRNA and protein expression [30, 33]; this effect is mediated by prolactin [34]. Some studies suggest that serotonin produced by the mammary 
gland during lactation may also stimulate parathyroid hormone-related protein synthesis and release [35].

\section{Serotonin}

Serotonin (5-hydroxytryptamine; 5HT) is produced in a variety of peripheral tissues, including the gut, bone, and mammary gland. It is synthesized by tryptophan hydroxylase-1 from L-tryptophan [20]. In the mammary gland, two actions of serotonin have been described: a negative feedback on milk synthesis and secretion, and a positive effect on parathyroid hormone-related protein synthesis and secretion [36]. Suckling is an important mechanism that regulates and maintains low levels of serotonin in milk. When the mammary gland is filled with milk, serotonin provides a negative feedback that inhibits milk synthesis in the mammary epithelium [37]. The expression of $\beta$-casein is suppressed in the mammary epithelial MCF-12A cells and is associated with the serotonin-7 receptor (5HT/) expression [37]. Furthermore, during lactation, serotonin has a negative control over the $\beta$-casein expression in the mammary gland through the serotonin-7 receptor (5HT7) expression [37], and increased mRNA abundance of calcium transporters Ncx1, Serca2, Spca2, Pmca2, and Sglt1, but not the calcium-sensing receptor expression in the mammary gland [35], and increased osteoclasts and resorption of bone [35]. However, these effects can also be mediated by parathyroid hormone-related protein.

\section{Changes in hormones and signals that modify morphology and function in the mammary gland during lactation}

\section{Glucocorticoids}

Glucocorticoids trigger differentiation of the secretory epithelium and milk production [38]. In the last part of the gestation, and in parturition, maternal cortisol increases sharply [39]. Although this increase in circulating glucocorticoids is not the primary trigger of lactogenesis, it has a permissive action for the prolactin effects on $\alpha$-lactalbumin and casein synthesis [39]. During lactation, glucocorticoid receptors act as a survival signal in the mammary gland [40] and inducer of milk protein gene expression and milk secretion [41, 42]. In addition, glucocorticoids and prolactin activate the prolactin-inducible protein (PIP) and exert an antiapoptotic effect on the mammary gland during lactation [43].

\section{Oxytocin}

Oxytocin is a peptide hormone synthesized in the hypothalamus, where it acts as a neurotransmitter. It is also released into the bloodstream via the posterior pituitary gland functioning as a hormone in peripheral targets [44]. During lactation, oxytocin increases in maternal circulation in response to suckling [45]. The hormone participates in milk ejection through the contraction of myoepithelial cells within the mammary tissue. It can also regulate osteoblast and osteoclast functions during lactation [46].

\section{Insulin}

Early studies revealed that in addition to insulin, prolactin and corticoids are also required to maintain the synthesis of milk components [47]; nevertheless, insulin is an important signal for milk production. Other investigations based on circulating concentrations of insulin and glucose at different days of lactation showed contrasting results. Women on the 3rd-4th day postpartum exhibited increased insulin levels [48]. In lactating humans and rats, suckling increases the insulin release $[49,50]$. In contrast, compared with non-lactating rats, 11-13 day lactating rats presented lower glucose and plasma insulin levels [8, 51], which can be explained by the high rate of glucose utilization and increased insulin sensitivity $[8,51]$ in the mammary gland. Molecular studies helped disclose the role of insulin, demonstrating that insulin receptor substrate- 1 expression and its transduction pathway via Akt1 increase dramatically in the mammary glands in lactation [21, 52-54], supporting the important role of this hormone in the mammary gland during lactation.

\section{Calcium-sensing receptor}

This receptor is a G-protein-coupled receptor that recognizes and responds to small changes in the extracellular ionized calcium concentration [55]. Currently, it is known that this receptor is present in the mammary gland [56] and bone [57]. The calcium-sensing receptor expression augments during lactation in the mammary gland [58] and functions as a feedback regulator during breastfeeding [58]. Hormonal changes at the start of lactation induce parathyroid hormone-related protein secretion that acts on bone cells to promote bone resorption and liberate calcium in circulation [59]. Circulating calcium, in turn, helps to control parathyroid hormone-related protein secretion in the mammary gland through the calcium-sensing receptor [59]. If the systemic calcium levels decline and calcium influx in the mammary gland decreases, then the calcium-sensing receptor expression in the mammary gland is reduced. These changes lead to increased parathyroid hormone-related protein secretion in the maternal circulation by the mammary epithelial cells to increase the release of calcium from bone reserves [59]. 


\section{Bone}

Bone is formed from different cell types: preosteoblasts, osteoblasts, bone-lining cells, osteocytes, preosteoclast, and osteoclast [60]. Osteocytes represent $90 \%$ of the total cells in the normal skeleton [61]. During lactation, bone plays a critical role in the release of minerals for milk synthesis.

\section{Bone changes during lactation}

Bone resorption and demineralization take place during lactation due to an increase in the number and activity of osteoclast [61]; nevertheless, osteocytes and osteoblast also participate in bone mass decrease. Osteocytes express the osteoclast-related genes that are upregulated during lactation and contribute to bone resorption during lactation (osteocytic osteolysis) [62]. Osteoblasts also increase; however, the bone turnover is in favor of bone mass loss, because the osteoclast and osteocyte activity is higher compared to osteoblasts [63].

\section{Hormonal signal changes that modify bone morphology during lactation}

The mechanisms that initiate bone loss during lactation are not fully understood; several hormones may participate in this process. Studies in rats demonstrated high prolactin levels induced bone density loss [64, 65]; however, prolactin induces bone density loss only during the late lactating period [64]. Both suckling and prolactin inhibit the pulse center of the gonadotropin-releasing hormone that suppresses the luteinizing and follicle-stimulating hormone. These hormonal changes result in diminished levels of progesterone and estradiol [66]; this decrease of steroid hormones along with serotonin-induced parathyroid hormone-related protein secretion by prolactin promotes bone resorption. Nevertheless, parathyroid hormone-related protein and decreased steroid hormone levels are not the only participants in the accelerated bone loss during lactation [67]. Among other factors that may participate is the fibroblast growth factor 21 (FGF21), a molecule that increases during lactation and whose ablation results in lack of bone resorption during lactation [68].

\section{Parathyroid hormone-related protein}

PTHrP secreted by the mammary gland during lactation is determinant for calcium milk supply through bone resorption [30, 31]. Several tissues produce parathyroid hormonerelated protein; however, this cannot be detected in the serum of healthy non-lactating individuals, suggesting this hormone functions locally in an autocrine or paracrine manner and acts as an endocrine factor only during lactation [3]. Parathyroid hormone-related protein is generated locally in bone and is essential for endochondral bone formation in neonates and maturity for bone remodeling $[69,70]$. As a hormone, parathyroid hormone-related protein-mediated actions are produced by binding to the $\mathrm{G}$ protein-coupled receptor [69]. In the bone, parathyroid hormone-related protein acts via the RANL/RANK signaling pathway, stimulating the tissue resorption and liberating skeletal calcium stores [69].

\section{Calcitonin}

Calcitonin is a hormone that regulates calcium homeostasis in vertebrates via osteoclast-mediated bone resorption and $\mathrm{Ca}^{2+}$ excretion by the kidney [71]. The hormone is produced primarily by the $\mathrm{C}$ cells of the thyroid gland [72]. Interestingly, the mammary epithelial cells are also an essential source of calcitonin during lactation [73]. However, it is unknown whether the breast, thyroid gland, or other cells are the source of the hormone during lactation. The effect of calcitonin is mediated by its receptors (CTRs), a member of the G-protein-coupled receptor (GPCR) [71]. Calcitonin levels during lactation are increased [3] and it might have an essential role in preventing excessive bone resorption [74].

\section{Intestinal changes during lactation}

Intestinal calcium absorption is normal in lactating women, but increased in rodents [3]. In rats, lactation induces morphological changes in the intestine [75], including increased length and weight [76, 77]. Wongdee et al. [75] found that lactating rats had higher villous heights in the ileum, duodenum, and jejunum compared with nulliparous rats. In addition to calcium, leucine and glucose absorption increased during lactation, reaching their peak at the 10th day of lactation [78]. Other changes in the gut of lactating rats include increased disaccharidase activities [79].

Prolactin stimulates intestinal calcium absorption in rodents $[65,75,80]$; however, hyperprolactinemia per se cannot explain the intestinal adaptive changes of lactation [81], suggesting that other factors may participate in this effect. Intestinal calcium absorption occurs through two different mechanisms: (1) the paracellular transport pathway, which is the result of passive diffusion, and (2) the active transcellular pathway, which is crucial during lactation when there is a high calcium demand. In intestine-like Caco-2 monolayer cells, prolactin increases the protein of the first step of the active transcellular pathway: voltagedependent L-type calcium channel (Cav) 1.3 [82]. Lactating mice increase the intestinal expression of the active transcellular transport proteins: the $1,25(\mathrm{OH}) 2 \mathrm{D}$-inducible epithelial 
calcium-selective channel (TRPV6) and the S100 calciumbinding protein $\mathrm{G}$ (S100G) [83]. However, no alterations were found in the passive diffusion protein expression of cation-permeable claudin-2, claudin-12, or claudin-15 [83]. Fibroblast growth factor (FGF)-23 is a negative regulator of calcium absorption and is increased perhaps as a compensatory mechanism to prevent calcium hyper-absorption $[75,80]$.

\section{Renal changes during lactation}

During lactation, urinary calcium excretion is decreased in rodents and humans to maintain calcium levels for milk production. This effect is mediated by both prolactin and parathyroid hormone-related protein, which stimulate calcium reabsorption $[3,59]$. At the molecular level, the expression of transient receptor potential cation channel subfamily $\mathrm{V}$ member 5 (Trpv5) and calbindin 1 (Calb1) was found to increase in the kidney of lactating mice; however, no changes were observed in claudins involved in $\mathrm{Ca}^{2+}$ and $\mathrm{Mg}^{2+}$ transport (claudin-2, claudin-14, claudin-16, or claudin-19) [83].

\section{Post-lactation}

The metabolic and histological changes needed for milk production are reverted after weaning. The mammary gland and the skeleton undergo rapid morphological changes, and the physiological actions shift toward restoration in the bone.

In rodents, studies conducted immediately after weaning reveled high plasma calcium levels [3, 84]. The transient hypercalcemic levels seen after weaning are likely a consequence of the decreased outflow of calcium into the mammary gland with concurrent bone reabsorption and release of calcium into circulation. One week after weaning, the plasma calcium levels returned to the normal range and remained steady afterward [3].

\section{Mammary gland in post-lactation}

After weaning, the mammary gland morphology remodels to reach the pre-pregnant state. These processes are mediated by local signals and changes in circulating levels of hormones [85]. Mammary gland involution initiates with the apoptosis of epithelial cells, the collapse of alveolar structures, a decrease in milk synthesis, and a rise in fat cells [85]. Involution of the mammary glands can be divided into two different stages: the first starts immediately upon weaning, lasts for about $48 \mathrm{~h}$, and is reversible [86]. This phase is regulated by local factors within the gland [85]. The second phase is controlled by hormonal factors [87]. The first involution stage is protease-independent and is triggered by milk stasis (milk synthesis, which remains in the mammary gland and cannot come out) within the alveolar lumen and the decrease in lactogenic prolactin levels [85]. In mice, the rapid involution during the first 2 days is related to the shedding of apoptotic bodies derived from the alveolar epithelial cells in alveolar lumens. The process is followed by a gradual regression in which macrophages phagocytose the apoptotic bodies within the epithelium [86]. In rats, glandular involution is more gradual and uniform with the shedding of the apoptotic epithelial cells in alveolar lumens being a lesser noticeable process [86]. The second phase of involution is characterized by proteolysis of the mammary gland basement membrane and tissue remodeling [85]. The mechanism is triggered by matrix metalloproteinases, the phagocytic clearance of apoptotic bodies, and the re-differentiation of adipocytes.

\section{Metabolic changes}

Since the increase in nutrient synthesis and transport are no longer required for milk production, the expression of GLUT1 [17], fatty acid-binding proteins [22], amino acids uptake [88], and the biochemical machinery for milk synthesis are decreased. Milk stasis has an essential role in this process $[85,88]$.

Several studies have focused on the signaling pathways that participate in mammary gland involution. As described above, in lactating rodents, the signaling pathway was governed by phosphorylated STAT5 for lobule-alveolar development and milk protein gene expression [89]. This pathway decreases within 3-6 h of milk stasis [90]. Then, STAT3 phosphorylation increases and its activity consequently enhances [90]. Expression and secretion of proinflammatory cytokine leukemia inhibitory factor (LIF) activate STAT3 [91]. STAT3 induces mammary epithelial cell death and suppression of cell survival signals through PI3K-AKTmediated survival signaling [92]. It also increases insulinlike growth factor binding protein-5 (IGFBP5) that affects proliferative IGF1 signaling [93]. Besides, the activation of nuclear factor- $\mathrm{\kappa B}(\mathrm{NF}-\mathrm{\kappa B})$, the increase of nitric oxide synthase 2 gene expression, and the subsequent increase in nitric oxide levels drive the decrease in milk levels and increase in the cleavage of caspase-3, promoting apoptosis $[94,95]$.

\section{Post-lactation changes in hormones and signals produced by the mammary gland}

The second phase of mammary gland involution involves the decay of hormones produced during lactation. Prolactin, a central orchestrator of mammary gland, changes during lactation and drops to the non-lactating serum levels, and, consequently, prolactin-induced parathyroid-related protein 
mammary production decreases [30, 31]. The expression of the calcium-sensing receptor decreases after the cessation of lactation [96]. In contrast, the increased serum serotonin levels observed during lactation remain high after 21 days of lactation [68]. Because mammary glands involute after lactation, these data suggest that other tissues may participate as serotonin sources during post-lactation.

\section{Post-lactation changes in hormones and signals that modify morphology and function in the mammary gland}

A decrease in glucocorticoids is required for breast involution and apoptosis. There is a significant decrease in glucocorticoid hormones 3 days after the end of lactation (34-14 nM) [87]. In contrast, serum insulin levels increase compared with those observed at day 7 of lactation [68]. Interestingly, these studies have also found that serum IGF-I levels, which remain constant during lactation, increased 21 days after the end of lactation [68].

\section{Bone in post-lactation}

In the post-lactation period, intense remineralization occurs with substantial increases in bone formation to reconstruct bone $[3,97,98]$. In mice, bone mineral content is recovered within 2-4 weeks after weaning and 4-8 weeks in rats [3]. In humans, dual-energy X-ray absorptiometry (DXA) studies reveal bone recovery 12 months after weaning [3].

Remineralization is a rapid process that starts with decrease of osteoclast population within $24 \mathrm{~h}$ after removal of pups [97]. At the molecular level, the expression of the receptor activator of nuclear factor $\mathrm{\kappa B}$ (RANK) decreases and osteoclast apoptosis increases 1 day after weaning. Osteocytic osteolysis also drops, and osteocytes start to express osteoblast-specific genes [62]. Furthermore, a trigger in the osteoblast number and an increase in bone density also contribute to the recovery of bone mass [97, 99]. In both animal and human studies, morphology data indicate that the skeleton is restored to its prior mineral content despite the marked trabecular microarchitectural deterioration during lactation [100].

The mechanisms and factors that stimulate bone recovery after weaning are still debatable. The reversed hormonal milieu produced by the decrease of prolactin - and increased to normal levels of gonadotropin-releasing hormone, luteinizing hormone, follicle-stimulating hormone, and estrogen-may participate in bone mineralization. A recent study found that estrogen increases osteoclasts apoptosis and decreases bone resorption through Fas/FasL pathway and receptor-interacting protein 140 (RIP140) [101]. However, the hypothalamic-pituitary-gonadal system is not determinant for bone remineralization [102]. Studies of the hormone profile in rats found that after $24 \mathrm{~h}$ of weaning, the maternal concentrations of prolactin decreased; and serum calcium, estrogen, and calcitonin were increased [97]. The increase of calcitonin does not seem to be required for bone remineralization, since bone mass is fully restored within 18 days after weaning in calcitonin/calcitonin gene-related peptide-alpha (Ctcgrp) null mice [98]. Other studies have revealed that skeletal recovery after lactation does not require osteoblastderived parathyroid hormone-related protein [103], parathyroid hormone [104], or vitamin D [105]. Compatible with osteoblast activity, the bone formation markers osteocalcin and procollagen type-1 amino-terminal propeptide (P1NP) were increased during post-weaning versus a pre-pregnancy baseline, pregnancy, and lactation [104].

Tibial microarray studies in mice comparing 7 days after weaning versus pre-pregnancy found that more than 700 genes had been differentially expressed. Some of these are related to the proliferation and activity of osteoblasts and the inhibition of osteoclasts [98]. There were decreased levels in cathepsin $\mathrm{K}-\mathrm{a}$ lysosomal cysteine protease involved in bone remodeling and resorption-as well as in IGF-binding protein 2, which stimulates bone resorption. Downregulation of Wnt family inhibitors was also observed. Protein transcripts involved in energy production pathways such as peroxisome proliferator-activated receptor coactivator-1 alpha (PGC1alpha), pyruvate dehydrogenase kinase, isoenzyme- 4 , and insulin-responsive glucose transporter-4 (GLUT-4; key transporter for glucose in osteoblasts) were increased to ensure energy for skeletal restoration [98].

\section{Intestinal changes in post-lactation}

Although the increased intestinal length produced during lactation partially diminishes after weaning, the gut does not completely regress by day 30 post-lactation $[77,78]$. Other studies in rats have shown that calcium transport in the intestine is increased in post-lactation, failing to attain control values by 3 weeks post-weaning [106]. Given the active remineralization and osteoblast proliferation in post-lactation, this suggests that increased absorption is likely used during this period to supply metabolites for bone regeneration.

\section{Conclusion}

Lactation is an evolutionary adaptation that gives mammals the opportunity to provide reliable nurturing to their offspring in face to uncertain access to food. A highly integrated maternal tissue network modifies its function to supply the different components needed for milk production in the mammary gland. In particular, skeletal demineralization is a refined strategy that assures calcium supply. The current literature principally documented the 


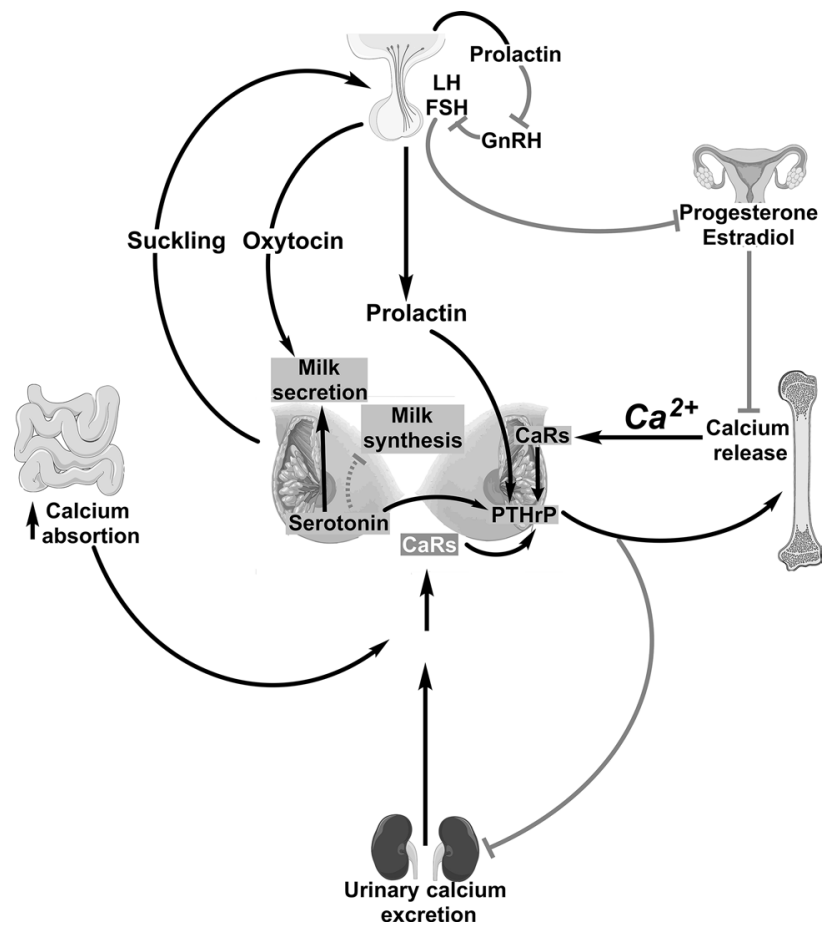

Fig. 2 Communication between different organs in lactation. Suckling stimulates the hypothalamus to secrete oxytocin and prolactin. Both suckling and prolactin inhibit the pulse center of gonadotropinreleasing hormone $(\mathrm{GnRH})$, which suppresses luteinizing hormone $(\mathrm{LH})$ and follicle-stimulating hormone (FSH). This decreases the levels of progesterone and estradiol. In the mammary glands, prolactin stimulates milk synthesis and secretion. Prolactin increases parathyroid hormone-related protein (PTHrP) secretion by mammary epithelial cells and its release in maternal circulation. The decrease of steroid hormones along with serotonin-induced PTHrP secretion by prolactin promotes bone resorption and liberates calcium in circulation. Circulating calcium in turn acts on the mammary gland calcium-sensing receptor to control PTHrP secretion. If the delivery of calcium to the gland decreases, then the resulting lower systemic calcium levels reduce receptor expression. This leads to increased PTHrP secretion by mammary epithelial cells and secretion into the maternal circulation to increase the supply of calcium from skeletal stores. PTHrP promotes renal calcium conservation. In lactating rodents, intestinal calcium absorption is increased. Continuous line arrows induced pathways; dotted lines inhibited pathways

changes produced in the mammary gland and in the skeleton; less information exists on the changes to the gut and kidney. In spite of the various models used, an integrated picture of the morphological, hormonal, and molecular changes that occur in lactation has emerged (Fig. 2). In contrast, most studies in post-lactation focus on mammary gland involution and morphological changes in bone structure, and there is little information on the factors and molecular mechanisms that take place in post-lactation. Identifying the factors involved in bone remineralization in post-lactation will help to develop therapeutic strategies for illness with bone loss.
Acknowledgements The authors are grateful to Dr. Karina PasténHidalgo and Dr. Leticia Riverón-Negrete for valuable discussions. This work was supported by Dirección General de Asuntos del Personal Académico, PAPIIT: IN 206617, Universidad Nacional Autónoma de México, and by Fondos Federales, Recursos Fiscales 2017 number 031/2015. Gustavo Canul Medina is a Ph.D. student from the Doctorado en Ciencias Biomédicas at UNAM and had a scholarship from Consejo Nacional de Ciencia y Tecnología (CONACYT) CVU416286 and from PAPIIT: IN 206617, Universidad Nacional Autónoma de México.

Author contributions GCM and CFM: revised the literature, and conceived and designed the manuscript and the figures. GCM: drew the figures. CFM: drafted and critically revised the article.

\section{Compliance with ethical standards}

Conflict of interest The authors declare that they have no conflict of interest.

\section{References}

1. Peacock M (2010) Calcium metabolism in health and disease. Clin J Am Soc Nephrol 5:S23-S30

2. Goldstein D (1990) Serum calcium. In: Walker HK, Hall WDHJ (eds) Clinical methods: the history, physical, and laboratory examinations. Butterworths, Boston

3. Kovacs CS (2016) Maternal mineral and bone metabolism during pregnancy, lactation, and post-weaning recovery. Physiol Rev 96:449-547

4. Inman JL, Robertson C, Mott JD, Bissell MJ (2015) Mammary gland development: cell fate specification, stem cells and the microenvironment. Development 142:1028-1042

5. Macias H, Hinck L (2012) Mammary gland development. Wiley Interdiscip Rev Dev Biol 1:533-557

6. Neville MC, McFadden TB, Forsyth I (2002) Hormonal regulation of mammary differentiation and milk secretion. J Mammary Gland Biol Neoplasia 7:49-66

7. Robinson AM, Girard JR, Williamson DH (1978) Evidence for a role of insulin in the regulation of lipogenesis in lactating rat mammary gland. Measurements of lipogenesis in vivo and plasma hormone concentrations in response to starvation and refeeding. Biochem J 176:343-346

8. Burnol AF, Ferre P, Leturque AGJ (1987) Effect of insulin on in vivo glucose utilization in individual tissues of anesthetized lactating rats. Am J Physiol 252:E183-E188

9. Guyette WA, Matusik RJ, Rosen JM (1979) Prolactin-mediated transcriptional and post-transcriptional control of casein gene expression. Cell 17:1013-1023

10. Collet C, Joseph R, Nicholas K (1991) A marsupial beta-lactoglobulin gene: characterization and prolactin-dependent expression. J Mol Endocrinol 6:9-16

11. Jagoda CA, Rillema JA (1991) Temporal effect of prolactin on the activities of lactose synthetase, alpha-lactalbumin, and galactosyl transferase in mouse mammary gland explants. Proc Soc Exp Biol Med 197:431-434

12. Hennighausen L, Westphal C, Sankaran LPC (1991) Regulation of expression of genes for milk proteins. Biotechnology 16:65-74

13. Waters SB, Rillema JA (1988) Effect of prolactin on enzymes of lipid biosynthesis in mammary gland explants. Am J Physiol 255(4 Pt 1):E567-E571 
14. Oppat CA, Rillema JA (1988) Characteristics of the early effect of prolactin on lactose biosynthesis in mouse mammary gland explants. Proc Soc Exp Biol Med 188:342-345

15. Williamson DH (1980) Integration of metabolism in tissues of the lactating rat. FEBS Lett 117:K93-K105

16. Zhao FQ (2014) Biology of glucose transport in the mammary gland. J Mammary Gland Biol Neoplasia 19:3-17

17. Camps M, Vilaro S, Testar X, Palacin M, Zorzano A (1994) High and polarized expression of glut 1 glucose transporters in epithelial cells from mammary gland: acute down-regulation of glut1 carriers by weaning. Endocrinology 134:924-934

18. Shennan DB, Peaker M (2000) Transport of milk constituents by the mammary gland. Physiol Rev 80:925-951

19. Shao Y, Wall EH, McFadden TB, Misra Y, Qian X, Blauwiekel R, Kerr D, Zhao FQ (2013) Lactogenic hormones stimulate expression of lipogenic genes but not glucose transporters in bovine mammary gland. Domest Anim Endocrinol 44:57-69

20. Laporta J, Peters TL, Merriman KE, Vezina CM, Hernandez LL (2013) Serotonin (5-HT) affects expression of liver metabolic enzymes and mammary gland glucose transporters during the transition from pregnancy to lactation. PLoS One 8:e57847

21. Rudolph MC, McManaman JL, Phang T, Russell T, Kominsky DJ, Serkova NJ, Stein T, Anderson SM, Neville MC (2007) Metabolic regulation in the lactating mammary gland: a lipid synthesizing machine. Physiol Genom 28:323-336

22. Zhang Y, Kallenberg C, Hyatt HW, Kavazis AN, Hood WR (2017) Change in the lipid transport capacity of the liver and blood during reproduction in rats. Front Physiol 8:517

23. Boxer RB, Stairs DB, Dugan KD, Notarfrancesco KL, Portocarrero CPP, Keister BA, Belka GK, Cho H, Rathmell JC, Thompson CBB, Birnbaum MJ, Chodosh LA (2006) Isoform-specific requirement for Akt1 in the developmental regulation of cellular metabolism during lactation. Cell Metab 4:475-490

24. Gregerson KA (2006) Prolactin: structure, function, and regulation of secretion. In: Knobil and Neill's physiology of reproduction, 3ed edn. Academic Press, Cambridge, MA, USA, pp $1703-1726$

25. Radhakrishnan A, Raju R, Tuladhar N, Subbannayya T, Thomas JK, Goel R, Telikicherla D, Palapetta SM, Rahiman BA, Venkatesh DD, Urmila KK, Harsha HC, Mathur PP, Prasad TSK, Pandey A, Shemanko C, Chatterjee A (2012) A pathway map of prolactin signaling. J Cell Commun Signal 6:169-173

26. Hennighausen L, Robinson GW (2005) Information networks in the mammary gland. Nat Rev Mol Cell Biol 6:715-725

27. Boyce BF, Xing L (2007) Biology of RANK, RANKL, and osteoprotegerin. Arthritis Res Ther 9(Suppl 1):S1

28. Horseman ND, Gregerson KA (2013) Prolactin actions. J Mol Endocrinol 52:R95-R106

29. Chen CC, Stairs DB, Boxer RB, Belka GK, Horseman ND, Alvarez JV, Chodosh LA (2012) Autocrine prolactin induced by the Pten-Akt pathway is required for lactation initiation and provides a direct link between the Akt and Stat5 pathways. Genes Dev 26:2154-2168

30. Lippuner K, Zehnder HJ, Casez JP, Takkinen R, Jaeger P (1996) $\mathrm{PTH}$-related protein is released into the mother's bloodstream during lactation: evidence for beneficial effects on maternal calcium-phosphate metabolism. J Bone Miner Res 11:1394-1399

31. Rakopoulos M, Vargas SJ, Gillespie MT, Ho PW, DiefenbachJagger H, Leaver DD, Grill V, Moseley JM, Danks JA, Martin TJ (2006) Production of parathyroid hormone-related protein by the rat mammary gland in pregnancy and lactation. Am J Physiol 263:E1077-E1085

32. Rabbani SA, Khalili P, Arakelian A, Pizzi H, Chen G, Goltzman D (2005) Regulation of parathyroid hormone-related peptide by estradiol: effect on tumor growth and metastasis in vitro and in vivo. Endocrinology 146:2885-2894
33. Yamamoto M, Fisher JE, Thiede MA, Caulfield MP, Rosenblatt M, Duong LT (1992) Concentrations of parathyroid hormonerelated protein in rat milk change with duration of lactation and interval from previous suckling, but not with milk calcium. Endocrinology 130:741-747

34. Thiede MA (1989) The mRNA encoding a parathyroid hormonelike peptide is produce in mammary tissue in response to elevations in serum prolactin. Mol Endocrinol 3:1443-1447

35. Laporta J, Peters TL, Weaver SR, Merriman KE, Hernandez LL (2013) Feeding 5-hydroxy-L-tryptophan during the transition from pregnancy to lactation increases calcium mobilization from bone in rats. Domest Anim Endocrinol 44:176-184

36. Marshall AM, Hernandez LL, Horseman ND (2014) Serotonin and serotonin transport in the regulation of lactation. J Mammary Gland Biol Neoplasia 19:139-146

37. Chiba T, Maeda T, Kudo K (2018) Endogenous serotonin and milk production regulation in the mammary gland. Yakugaku Zasshi 138:829-836

38. Reichardt HM, Horsch K, Gröne HJ, Kolbus A, Beug H, Hynes N, Schütz G (2001) Mammary gland development and lactation are controlled by different glucocorticoid receptor activities. Eur J Endocrinol 145:519-527

39. Hollanders JJ, Heijboer AC, van der Voorn B, Rotteveel J, Finken MJJ (2017) Nutritional programming by glucocorticoids in breast milk: targets, mechanisms and possible implications. Best Pract Res Clin Endocrinol Metab 31:397-408

40. Moran TJ, Gray S, Mikosz CA, Conzen SD (2000) The glucocorticoid receptor mediates a survival signal in human mammary epithelial cells. Cancer Res 60:867-872

41. Schwalm JW, Tucker A (1978) Glucocorticoids in mammary secretions and blood serum during reproduction and lactation and distributions of glucocorticoids, progesterone, and estrogens in fractions of milk. J Dairy Sci 61:550-560

42. Lechner J, Welte T, Tomasi JK, Bruno P, Cairns C, Gustafsson JÅ, Doppler W (1997) Promoter-dependent synergy between glucocorticoid receptor and Stat5 in the activation of $\beta$-casein gene transcription. J Biol Chem 272:20954-20960

43. Shiu RP, Iwasiow BM (1985) Prolactin-inducible proteins in human breast cancer cells. J Biol Chem 260:11307-11313

44. Swaab DF, Pool CW, Nijveldt F (1975) Immunofluorescence of vasopressin and oxytocin in the rat hypothalamo-neurohypophyseal system. J Neural Transm 36:195-215

45. Gimpl G, Fahrenholz F (2001) The oxytocin receptor system: structure, function, and regulation. Physiol Rev 81:629-683

46. Liu X, Shimono K, Zhu LL, Li J, Peng Y, Imam A, Iqbal J, Moonga S, Colaianni G, Su C, Lu Z, Iwamoto M, Pacifici M, Zallone A, Sun L, Zaidi M (2009) Oxytocin deficiency impairs maternal skeletal remodeling. Biochem Biophys Res Commun 388:161-166

47. Topper YJ, Freeman CS (1980) Multiple hormone interactions in the developmental biology of the mammary gland. Physiol Rev 60:1049-1106

48. Franceschini R, Ragni N, Cataldi A, Venturini PL, Barreca T, Rolandi E (1990) Influence of suckling on plasma concentrations of somatostatin, insulin and gastrin in lactating women. Int $\mathbf{J}$ Gynaecol Obstet 33:321-323

49. Widström AM, Winberg J, Werner S, Hamberger B, Eneroth P, Uvnäs-Moberg K (1984) Suckling in lactating women stimulates the secretion of insulin and prolactin without concomitant effects on gastrin, growth hormone, calcitonin, vasopressin or catecholamines. Early Hum Dev 10:115-122

50. Eriksson M, Björkstrand E, Smedh U, Alster P, Matthiesen ASUMK (1994) Role of vagal nerve activity during suckling. Effects on plasma levels of oxytocin, prolactin, VIP, somatostatin, insulin, glucagon, glucose and of milk secretion in lactating rats. Acta Physiol Scand 151:453-459 
51. Burnol AF, Leturque A, Ferre P, Kande J, Girard J (1986) Increased insulin sensitivity and responsiveness during lactation in rats. Am J Physiol 251:E537-E541

52. Lee A, Zhang P, Ivanova M, Bonnette S, Oesterreich S, Rosen JM, Grimm S, Hovey RC, Vonderhaar BK, Kahn CR, Torres D, George J, Mohsin S, Allred DC, Hadsell DL (2003) Developmental and hormonal signals dramatically alter the localization and abundance of insulin receptor substrate proteins in the mammary gland. Endocrinology 144:2683-2694

53. Berlato C, Doppler W (2009) Selective response to insulin versus insulin-like growth factor-I and -II and up-regulation of insulin receptor splice variant $B$ in the differentiated mouse mammary epithelium. Endocrinology 150:2924-2933

54. Lemay DG, Ballard OA, Hughes MA, Morrow AL, Horseman ND, Lemay DG, Ballard OA, Hughes MA, Morrow AL, Horseman ND, Nommsen-Rivers LA (2013) RNA sequencing of the human milk fat layer transcriptome reveals distinct gene expression profiles at three stages of lactation. PLoS One 8:e67531

55. Brown EM, MacLeod RJ (2001) Extracellular calcium sensing and extracellular calcium signaling. Physiol Rev 81:239-297

56. VanHouten J (2005) Calcium sensing by the mammary gland. J Mammary Gland Biol Neoplasia 10:129-139

57. Caudarella R, Vescini F, Buffa A, Rizzoli E, Ceccoli L, Francucci CM (2011) Role of calcium-sensing receptor in bone biology. J Endocrinol Invest 34:13-17

58. VanHouten J, Dann P, McGeoch G, Brown EM, Krapcho K, Neville M, Wysolmerski JJ (2004) The calcium-sensing receptor regulates mammary gland parathyroid hormonerelated protein production and calcium transport. J Clin Inves 113:598-608

59. Vanhouten JN, Wysolmerski JJ (2013) The calcium-sensing receptor in the breast. Best Pract Res Clin Endocrinol Metab 27:403-414

60. Clarke B (2008) Normal bone anatomy and physiology. Clin J Am Soc Nephrol 3(Suppl):S131-S139

61. Baron R (2008) Anatomy and ultrastructure of bone-histogenesis, growth and remodelling. Endotext, South Dartmouth

62. Teti A, Zallone A (2009) Do osteocytes contribute to bone mineral homeostasis? Osteocytic osteolysis revisited. Bone 44:11-16

63. Tojo Y, Kurabayashi T, Honda A, Yamamoto Y, Yahata T, Takakuwa K, Tanaka K (1998) Bone structural and metabolic changes at the end of pregnancy and lactation in rats. Am $\mathrm{J}$ Obstet Gynecol 178:180-185

64. Suntornsaratoon P, Wongdee K, Krishnamra N, Charoenphandhu $\mathrm{N}$ (2009) Femoral bone mineral density and bone mineral content in bromocriptine-treated pregnant and lactating rats. J Physiol Sci 60:1-8

65. Thongchote K, Charoenphandhu N, Krishnamra N (2008) High physiological prolactin induced by pituitary transplantation decreases BMD and BMC in the femoral metaphysis, but not in the diaphysis of adult female rats. J Physiol Sci 58:39-45

66. Hall JE, Guyton AC (2000) Textbook of medical physiology. Saunders Elsevier, Philadelphia

67. Ardeshirpour L, Brian S, Dann P, VanHouten J, Wysolmerski J (2010) Increased PTHrP and decreased estrogens alter bone turnover but do not reproduce the full effects of lactation on the skeleton. Endocrinology 151:5591-5601

68. Bornstein S, Brown SA, Le PT, Wang X, DeMambro V, Horowitz MC, MacDougald O, Baron R, Lotinun S, Karsenty G, Wei W, Ferron M, Kovacs CS, Clemmons D, Wan Y, Rosen CJ (2014) FGF-21 and skeletal remodeling during and after lactation in C57BL/6J mice. Endocrinology 155:3516-3526

69. Martin TJ (2016) Parathyroid hormone-related protein, its regulation of cartilage and bone development, and role in treating bone diseases. Physiol Rev 96:831-871
70. Wongdee K, Krishnamra N, Charoenphandhu N (2012) Endochondral bone growth, bone calcium accretion, and bone mineral density: how are they related? J Physiol Sci 62:299-307

71. Pondel M (2000) Calcitonin and calcitonin receptors: bone and beyond. Int J Exp Pathol 81:405-422

72. Foster GV, Baghdiantz A, Kumar MA, Slack E, Soliman HA, MacIntyre I (1964) Thyroid origin of calcitonin. Nature 27:1303-1305

73. Bucht E, Telenius-Berg M, Lundell G, Sjöberg HE (1987) Immunoextracted calcitonin in milk and plasma from totally thyroidectomized women. Evidence of monomeric calcitonin in plasma during pregnancy and lactation. Acta Endocrinol (Copenh) 113:529-535

74. Wysolmerski JJ (2010) Interactions between breast, bone, and brain regulate mineral and skeletal metabolism during lactation. Ann N Y Acad Sci 1192:161-169

75. Wongdee K, Teerapornpuntakit J, Sripong C, Longkunan A, Chankamngoen W, Keadsai C, Kraidith K, Krishnamra N, Charoenphandhu N (2016) Intestinal mucosal changes and upregulated calcium transporter and FGF-23 expression during lactation: contribution of lactogenic hormone prolactin. Arch Biochem Biophys 590:109-117

76. Fell BF, Smith KA, Campbell RM (1963) Hypertrophic and hyperplastic changes in the alimentary canal of the lactating rat. J Pathol Bacteriol 85:179-188

77. Craft IL (1970) The influence of pregnancy and lactation on the morphology and absorptive capacity of the rat small intestine. Clin Sci 38(287):287-295

78. Cripps AW, Williams VJ (1975) The effect of pregnancy and lactation on food intake, gastrointestinal anatomy and the absorptive capacity of the small intestine in the albino rat. Br J Nutr 33:17-32

79. Prieto RM, Ferrer M, Rayó JM, Tur JA (1994) Disaccharidase activities in pregnant and lactating rats. Comp Biochem Physiol A Physiol 109:741-747

80. Wongdee K, Rodrat M, Teerapornpuntakit J, Krishnamra N, Charoenphandhu N (2019) Factors inhibiting intestinal calcium absorption: hormones and luminal factors that prevent excessive calcium uptake. J Physiol Sci 11:1-14

81. Muller E, Dowling RH (1981) Prolactin and the small intestine. Effect of hyperprolactinaemia on mucosal structure in the rat. Gut 22:558-565

82. Nakkrasae LI, Thongon N, Thongbunchoo J, Krishnamra N, Charoenphandhu N (2010) Transepithelial calcium transport in prolactin-exposed intestine-like Caco- 2 monolayer after combinatorial knockdown of TRPV5, TRPV6 and Ca v1.3. J Physiol Sci 60:9-17

83. Beggs MR, Appel I, Svenningsen P, Skjødt K, Alexander RT, Dimke H (2017) Expression of transcellular and paracellular calcium and magnesium transport proteins in renal and intestinal epithelia during lactation. Am J Physiol Renal Physiol 313:F629-F640

84. Hodnett DW, DeLuca HF, Jorgensen NA (1992) Intestine, bone, and mammary gland contributions to maternal plasma calcium increase after abrupt weaning. Proc Soc Exp Biol Med 199:332-336

85. Watson CJ (2006) Involution: apoptosis and tissue remodelling that convert the mammary gland from milk factory to a quiescent organ. Breast Cancer Res 8:203

86. Walker NI, Bennett RE, Kerr JFR (1989) Cell death by apoptosis during involution of the lactating breast in mice and rats. Am J Anat 185:19-32

87. Feng Z, Marti A, Jehn B, Altermatt HJ, Chicaiza G, Jaggi R (1995) Glucocorticoid and progesterone inhibit involution and programmed cell death in the mouse mammary gland. J Cell Biol 131:1095-1103 
88. Viña JR, Puertes IR, Viña J (1981) Effect of premature weaning on amino acid uptake by the mammary gland of lactating rats. Biochem J 200:705-708

89. Humphreys RC, Hennighausen L (1999) Signal transducer and activator of transcription 5a influences mammary epithelial cell survival and tumorigenesis. Cell Growth Differ 10:685-694

90. Philp JA, Burdon TG, Watson CJ (1996) Differential activation of STATs 3 and 5 during mammary gland development. FEBS Lett 396:77-80

91. Schere-Levy C, Buggiano V, Quaglino A, Gattelli A, Cirio MC, Piazzon I, Vanzulli S, Kordon EC (2003) Leukemia inhibitory factor induces apoptosis of the mammary epithelial cells and participates in mouse mammary gland involution. Exp Cell Res 282:35-47

92. Abell K, Bilancio A, Clarkson RWE, Tiffen PG, Altaparmakov AI, Burdon TG, Asano T, Vanhaesebroeck B, Watson CJ (2005) Stat3-induced apoptosis requires a molecular switch in $\mathrm{PI}(3) \mathrm{K}$ subunit composition. Nat Cell Biol 7:392-398

93. Tonner E, Barber MC, Travers MT, Logan A, Flint DJ (1997) Hormonal control of insulin-like growth factor-binding protein-5 production in the involuting mammary gland of the rat. Endocrinology 138:5101-5107

94. Srivastava S, Matsuda M, Hou Z, Bailey JP, Kitazawa R, Herbst MP, Horseman ND (2003) Receptor activator of NF-kappaB ligand induction via Jak2 and Stat5a in mammary epithelial cells. J Biol Chem 278:46171-46178

95. Zaragozá R, Bosch A, García C, Sandoval J, Serna E, Torres L, García-Trevijano ER, Viña JR (2010) Nitric oxide triggers mammary gland involution after weaning: remodelling is delayed but not impaired in mice lacking inducible nitric oxide synthase. Biochem J 428:451-462

96. Kim W, Wysolmerski JJ (2016) Calcium-sensing receptor in breast physiology and cancer. Front Physiol 7:440

97. Miller SC, Bowman BM (2007) Rapid inactivation and apoptosis of osteoclasts in the maternal skeleton during the bone remodeling reversal at the end of lactation. Anat Rec (Hoboken) 290:65-73

98. Collins JN, Kirby BJ, Woodrow JP, Gagel RF, Rosen CJ, Sims NA, Kovacs CS (2013) Lactating Ctcgrp nulls lose twice the normal bone mineral content due to fewer osteoblasts and more osteoclasts, whereas bone mass is fully restored after weaning in association with up-regulation of Wnt signaling and other novel genes. Endocrinology 154:1400-1413

99. Ardeshirpour L, Dann P, Adams DJ, Nelson T, Vanhouten J, Horowitz MC, Wysolmerski JJ (2007) Weaning triggers a decrease in receptor activator of nuclear factor- $\mathrm{\kappa B}$ ligand expression, widespread osteoclast apoptosis, and rapid recovery of bone mass after lactation in mice. Endocrinology 148:3875-3886

100. Kovacs CS (2017) The skeleton is a storehouse of mineral that is plundered during lactation and (fully?) replenished afterwards. J Bone Miner Res 32:676-680

101. Piao H, Chu X, Lv W, Zhao Y (2017) Involvement of receptorinteracting protein 140 in estrogen-mediated osteoclasts differentiation, apoptosis, and bone resorption. J Physiol Sci 67:141-150

102. Revilla R, Revilla M, Hernández ER, Villa LF, Varela L, Rico $\mathrm{H}$ (1995) Evidence that the loss of bone mass induced by GnRH agonists is not totally recovered. Maturitas 22:145-150

103. Kirby BJ, Ardeshirpour L, Woodrow JP, Wysolmerski JJ, Sims NA, Karaplis AC, Kovacs CS (2011) Skeletal recovery after weaning does not require PTHrP. J Bone Miner Res 26:1242-1251

104. Kirby BJ, Ma Y, Martin HM, Buckle Favaro KL, Karaplis AC, Kovacs CS (2013) Upregulation of calcitriol during pregnancy and skeletal recovery after lactation do not require parathyroid hormone. J Bone Miner Res 28:1987-2000

105. Miller SC, Halloran BP, DeLuca HF, Jee WSS (1982) Role of vitamin $\mathrm{D}$ in maternal skeletal changes during pregnancy and lactation: a histomorphometric study. Calcif Tissue Int 34:245-252

106. Halloran BP, DeLuca HF (1980) Calcium transport in small intestine during pregnancy and lactation. Am J Physiol 239:E64-E68

Publisher's Note Springer Nature remains neutral with regard to jurisdictional claims in published maps and institutional affiliations. 